\title{
Quality Of Life Analysis: Socio-Economic Perspective With Reference To Jharia Coalfield
}

\author{
Twisha Adhikary ${ }^{1}$, Dr. Manjari Bhattacharji ${ }^{2}$, Shri. Achyuta Krishna Ghosh ${ }^{3}$ \\ ${ }^{I}$ Ph.D Scholar, Dept. Of Geography, Visva Bharati University, Santiniketan, India. \\ ${ }^{2}$ Associate Professor, Dept. Of Geography, Visva Bharati University, Santiniketan, India. \\ ${ }^{3}$ Scientist \& Senior Deputy Director, Central Institute of Mining \& Fuel Research, Dhanbad, India.
}

\begin{abstract}
The paper makes an attempt to study the various aspects of Quality of Life (QOL) from socioeconomic perspective. While doing so, certain definitions of $Q O L$ and its ingredients have been studied.The significance of socio-economic parameters in the study of QOL has been highlighted. Socio-economic factors are not universal and may vary from place to place and time to time. As a case study, Jharia Coalfield region is studied and a methodology is prepared to evaluate the quality of life index of the region. While studying the Jharia Coalfield region, the history of coal mining there and the issues of $Q O L$ in mining areas have been studied.Issues of QOL in coal mining areas include the material dimensions, non-material diemnsions and the environmental dimensions. The utilization of the land there and the settlement pattern are shown. Based on technical information about the stability of the land, study areas are selected. In the selected study areas, socioeconomic survey is conducted and QOL index is formulated.
\end{abstract}

Keywords: Index of Availability, Index of Satisfaction, Quality of Life, Resettlement and Rehabilitation, Socioeconomic parameters, Stability of land.

\section{Introduction}

The term quality of life (QOL) is used to evaluate the general well-being of individuals and societies. The term is used in a wide range of contexts, including the fields of international development, healthcare, and politics. Quality of life should not be confused with the concept of standard of living, which is based primarily on income. Instead, standard indicators of the quality of life include not only wealth and employment, but also the environment, physical and mental health, education, recreation and leisure time, and social belonging.

Analysis of the concept of Quality of Life has clearly established the fact that for evaluation of QOL of any place, we need to know the condition of living of the people in that particular place. Condition of living encompasses the entire environment in which the people are leading their life. Surrounding environment includes not only physical environment but also includes social, cultural, political and economic environment.

But QOL analysis is not just the study of these existing environments. It is more complex than it appears. The surrounding environment has to be studied from two perspectives - objective and subjective. Objective analysis highlights the availability of some basic parameters. On the other hand, subjective analysis highlights the satisfaction of the people for whom the amenities are provided. Satisfaction of the people is about the availability of amenities as well as the affordability on the part of the people. This gives the actual view of the satisfaction quotient or in other words happiness quotient of the people.

First attempt of such a study was made in the year 2003-2005. A study was jointly conducted by CIMFR and NISM, in the coastal areas of Orissa, Kerala and Kanyakumari to evaluate the QOL of the people living around the beach placer mining areas.

The present study is done in Jharia Coalfield of Dhanbad district, Jharkhand. Due to long time mining and unscientific mining practices several parts of the coalfield have become vulnerable not only for the miners but also for the resident population. In order to avoid large scale human disaster, loss of valuable resources and environmental destruction, it is important that the quality of life index of the people be evaluated with elaborative socio- economic survey. This will lead to identification of vulnerable areas and the cause of its vulnerability. By following this technique the final aim is to assist the Government at all levels, i.e., local, state and national, to formulate an appropriate resettlement and rehabilitation program for the vulnerable residents of Jharia Coalfield.

\section{What Is Quality Of Life (Qol)?}

QOL is considered by different authors as an "abstract", "soft", "amorphous" concept (Birren and Dieckmann, 1991, pp. 344-345); as one that "has no fixed boundaries" (Hughes, 1990, p. 47); that "has been exceedingly difficult to define (it) precisely" (Andersen, Davidson, \& Ganz, 1994, p. 367); that is "difficult to operationalize" (Lawton, 1991); and, even, as one whose "meaning is dependent of the user of the term" (Fowlie 
\& Berkeley, 1987, p. 226). QOL has been defined as equivalent to well-being in the social domain (Campbell, 1981), to the health status in the bio-medical field (also called health-related QOL, Naughton \& Wiklund, 1993), and to life satisfaction in the psychology field (Palys \& Little, 1983).

In accordance with Birren and Dieckmann (1991), it can be established what is not quality of life: QOL is not equivalent of quality of the environment, is not equal to the quantity of material goods, is not equivalent to the physical health status, or to the quality of health care, just as it is distinct from subjective constructs such as life satisfaction, morale or happiness (Campbell, 1981; George \& Bearon, 1980; Naughton \& Wiklund, 1993). As Browne et al. (1994, p. 235) stated: "Quality of Life (QOL) is the product of the dynamic interaction between external conditions of an individual's life and the internal perceptions of those conditions". Thus, we cannot reduce this concept to life's external conditions or to personal characteristics, even the perception of external conditions.

According to ecological economist Robert Costanza, while QOL has long been an explicit or implicit policy goal, adequate definition and measurement have been elusive. Diverse "objective" and "subjective" indicators across a range of disciplines and scales, and recent work on subjective well-being (SWB) surveys and the psychology of happiness have spurred renewed interest.

Also frequently related are concepts such as freedom, human rights, and happiness. However, since happiness is subjective and hard to measure, other measures are generally given priority. It has also been shown that happiness, as much as it can be measured, does not necessarily increase correspondingly with the comfort that results from increasing income. As a result, standard of living should not be taken to be a measure of happiness.

Working from these distinctions, we arrive at a general, commonly accepted, characteristic of QOL: its multidimensionality. That is, like life, QOL is multidimensional by nature. Even if we are applying this concept in a specific context, QOL must be operationalized by means of a set of dimensions. What are these dimensions; in other words, what are the "ingredients" of QOL?

\section{The Ingredients Of Qol}

Two strategies have been used in the definition of the constituent elements, domains, aspects, components, factors, or content areas of QOL: theoretical and empirical.

From a theoretical perspective, several authors have formulated models of QOL; for example, Lawton (1991, p. 8) proposed a four-sector model in which psychological well-being, perceived quality of life, behavioral competence, and objective environment are hypothesized as the four general evaluative sectors: "Each of the four sectors may in turn be differentiated into as many dimensions as the details of one's attention demand".

On similar lines, the World Health Organization (1993) has conceptualized QOL in terms of five broad domains: physical health, psychological health, level of independence, social relationship, and environment.

Finally, other authors have tried to develop categories of QOL dimensions. For example, Hughes (1990) defined seven categories:

1. Individual characteristics (functional activities, physical and mental health, dependency, etc.).

2. Physical environmental factors (facilities and amenities, comfort, security, etc.).

3. Social environmental factors (levels of social and recreational activity, family and social network, etc.).

4. Socio-economic factors (income, socio-economic status, etc.).

5. Personal autonomy factors (ability to make choices, exercise control, etc.).

6. Subjective satisfaction.

7. Personality factors (psychological well-being, morale, life satisfaction, happiness, etc.).

A second strategy used for defining QOL components is empirical. That is, since QOL refers to individual's lives, individuals must be asked to state the implicit domains of their QOL concept. For example, Flanagan (1978) assessed QOL components through a US survey of three age group samples. Fifteen critical components were grouped into five main categories:

1. Physical and material well-being (material well-being and financial security).

2. Relations with other people (relations with spouse and having and raising children, relations with parents, siblings, or other relatives, relations with friends).

3. Social, community and civic activities (activities related to helping or encouraging other people, activities related to local and national governments).

4. Personal development and fulfilment (intellectual development, personal understanding and planning, occupational role, creativity and personal expression).

5. Recreation (socializing, passive and observational activities, active and participatory recreational activities). 
The best way of approaching quality of life measurement is to measure the extent to which people's 'happiness requirements' are met - ie those requirements which are a necessary (although not sufficient) condition of anyone's happiness - those 'without which no member of the human race can be happy.'

\section{- McCall, S.: 1975, 'Quality of Life', Social Indicators Research 2, pp 229-248}

QOL may be defined as subjective well-being. Recognising the subjectivity of QOL is a key to understanding this construct. QOL reflects the difference, the gap, between the hopes and expectations of a person and their present experience. Human adaptation is such that life expectations are usually adjusted so as to lie within the realm of what the individual perceives to be possible. This enables people who have difficult life circumstances to maintain a reasonable QOL.

\section{- Janssen Quality-of-life Studies}

In quality of life research one often distinguishes between the subjective and objective quality of life. Subjective quality of life is about feeling good and being satisfied with things in general. Objective quality of life is about fulfilling the societal and cultural demands for material wealth, social status and physical wellbeing.

\section{- Quality-of-Life Research Center, Denmark}

The approach to the measurement of the quality of life derives from the position that there are a number of domains of living. Each domain contributes to one's overall assessment of the quality of life. The domains include family and friends, work, neighbourhood (shelter), community, health, education, and spiritual.

\section{- The University of Oklahoma School of Social Work}

The City of Vancouver measures QOL using the following indicators: Community Affordability Measure, Quality of Employment Measure, Quality of Housing Measure, Health Community Measure, Community Social Infrastructure, Human Capital Measure, Community Stress Measure, Community Safety Measure, and Community Participation Measure.

UNDP has been publishing the annual Human Development Index (HDI) for countries around the world. It examines the health, education and wealth of each nation's citizens by measuring:

1. life expectancy

2. educational achievement -- adult literacy plus combined primary, secondary and tertiary

3. Standard of living -- real GDP per capita based on PPP exchange rates. enrolment;

\section{- Human Development Report, UNDP, 1997}

Quality of Life is the product of the interplay among social, health, economic and environmental conditions which affect human and social development.

\section{-Ontario Social Development Council, 1997}

\section{Socio-Economic Parameters}

Analysis of the concept of Quality of Life has clearly established the fact that for evaluation of QOL of any place, we need to know the condition of living of the people in that particular place. Condition of living encompasses the entire environment in which the people are leading their life. Surrounding environment includes not only physical environment but also includes social, cultural, political and economic environment.

But QOL analysis is not just the study of these existing environments. It is more complex than it appears. The surrounding environment has to be studied from two perspectives - objective and subjective. Objective analysis highlights the availability of some basic parameters. On the other hand, subjective analysis highlights the satisfaction of the people for whom the amenities are provided. Satisfaction of the people is about the availability of amenities as well as the affordability on the part of the people. This gives the actual view of the satisfaction quotient or in other words happiness quotient of the people. Therefore, for QOL analysis, firstly certain parameters has to be selected which will represent the entire surrounding or environment of the people living there.

In the year 2003-2005, a study was jointly conducted by CIMFR and NISM, in the coastal areas of Orissa, Kerala and Kanyakumari to evaluate the QOL of the people living around the beach placer mining areas. In this study, some socio-economic parameters were selected which were considered to be significant for these coastal villages. The parameters selected were as follows: 


\begin{tabular}{|l|l|}
\hline Housing & Quality of Water \\
\hline Education & Quantity of Water \\
\hline Income \& employment & Drainage and Sanitation \\
\hline Market & Physical and social environment \\
\hline Medical facility & Recreation facility \\
\hline Transport \& communication & Social security \\
\hline Fuel availability & Human rights \\
\hline Electricity supply & \\
\hline
\end{tabular}

Studying these parameters reveal that they are the basic needs for survival of mankind. Therefore, it can be assumed that these set of parameters will remain the same everywhere around the world while QOL is analysed. But this set of parameters is not universal. In some place, a completely different socio-economic factor may be significant for the life of the people there and therefore will be significant for QOL analysis in that place.
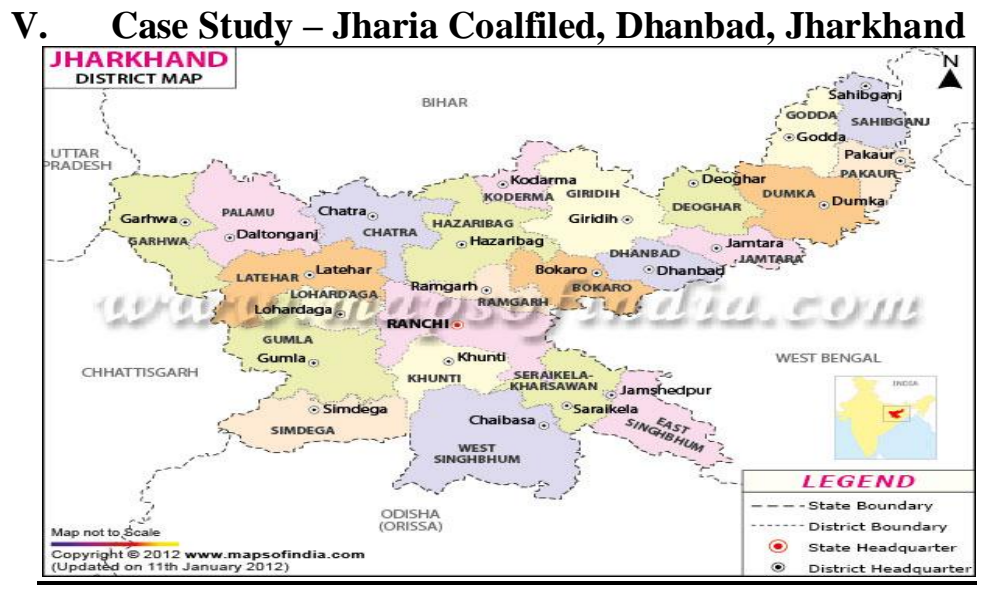

\subsection{Objective Of The Study}

Development of an approach for evaluation of quality of life in different social, economic and environmental situations and its application in selected sites in five mining areas of Jharia Coalfield.

\subsection{Backdrop Of The Study}

Due to long time mining and unscientific mining practices several parts of the JCF have become vulnerable not only for the miners but also for the resident population. In order to avoid large scale human disaster, loss of valuable resources and environmental destruction, the Government of India has initiated an $R \& R$ program of resident population and mining activities as a whole. In order to do this it is necessary to identify the vulnerability of each of the mining areas and rank them accordingly so that R\&R programs can be initiated on a priority basis.

\subsection{Justification}

Against this backdrop the objective of the study is to identify the levels of vulnerability through an analysis of the QOL of the resident population and the status of vulnerability of each mining area.

The technical dimensions of the vulnerability of the mining areas is beyond the purview of the geographer hence, this is not taken into account in the present study. The impact of the technical vulnerabilities of the mining areas are reflected in the QOL of the resident population. This justifies the QOL of the mining areas.

\subsection{The Study Area}

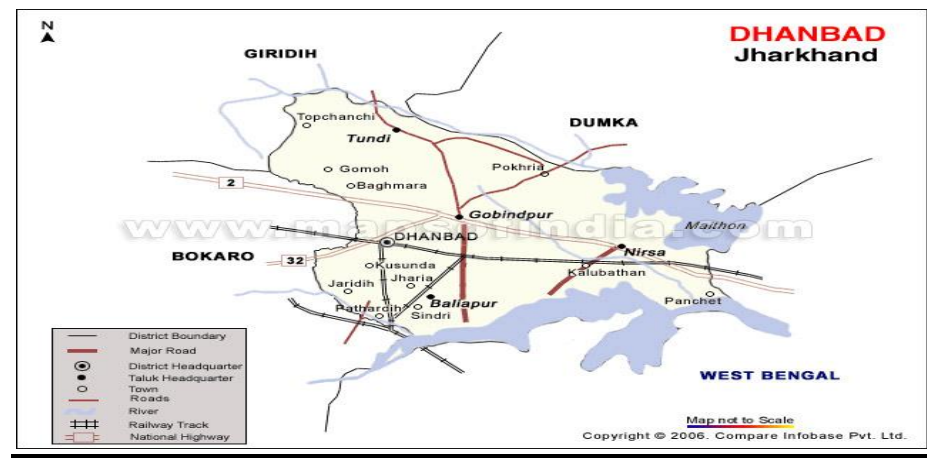


Located between $23^{0} 39^{\prime} \mathrm{N}$ to $23^{\circ} 48^{\prime} \mathrm{N}$ latitude and $86^{\circ} 11^{\prime} \mathrm{E}$ to $86^{\circ} 27^{\prime} \mathrm{E}$ longitude on the north of the Damodar River in Dhanbad district in Jharkhand, the sickle shaped Jharia Coalfield (JCF) with an area of about 450 sq. km. is the only source of prime coking coal in India, and obviously it has very substantial implications for Jharkhand.

As JCF came into prominence as a hub of coal mining activities, the township of Jharia started coming up around 1898 (CMRI, 1997). Concentrated growth of dwellings in this town and its suburbs were the natural outcome of industrial growth.

The inhabitation on mineable land was promoted because of the lack of foresight on the rapid expansion of this industry, and its subsequent adverse effects on environment and in turn on the upcoming settlements and their people. Development and growth of this area as well as that of the whole Dhanbad district took place solely based on the coal mining in JCF.

JCF has a mixed population composed mainly of settlers who have migrated here from almost all states of India for their profession leading to a steady upsurge in the concentration of settlements.

There are more than 100 urban and rural, organised and unorganised, legal as well as illegal settlements in this coalfield (Saxena, 2003,i). These settlements have been coming up unabated in spite of the Coal Bearing Area (Acquisition \& Development) Act, 1957 and Mineral Area Development Authority (MADA) Regulations (Saxena, 2003,ii) coming into being to restrict growth of structures over the mining land. Many of these constructions are unplanned and some have been built on mined out or active mining areas, which are either already affected or may be affected in immediate future, by fire and/or subsidence.

From the above discussion of the environmental and social conditions in Jharia, we find that there are some parameters which are significant for determining the QOL of the people here. Therefore, along with the above mentioned parameters, some other significant aspects have to be included for the study. They are as follows:

1. Stability of dwellings

2. Type of land ownership

\subsection{Issues Of Qol In Mining Areas \\ 5.5.1 Material Dimension \\ * Housing \\ * Quality of Water \\ * Education \\ * Quantity of Water \\ * Income \& employment \\ * Drainage and Sanitation \\ * Market \\ * Social environment \\ * Medical facility \\ * Recreation facility \\ * Transport \& communication \\ * Electricity supply}

\subsubsection{Non-Material Dimensions}

Concept Of Satisfaction Level And Level Of Availability Of Socio-Economic Parameters:

- Status of any socio-economic parameter in an area is determined by two aspects. One is its availability in the area and second is the level of satisfaction enjoyed by the people due to the availability of that parameter.

- Level of Availability is easy to determine and is obtained from the actual field condition. But Level of Satisfaction is a relative concept and varies from person to person in any same condition or in different conditions. Irrespective of the availability of any particular parameter, the level of satisfaction among the people regarding its availability will depend on the people itself. Purchasing power, social and economic status, requirement, and attitude are some of the factors that determine the level of satisfaction of the sample regarding any particular parameter. So in any given circumstance with all other conditions remaining the same, level of satisfaction may vary from person to person.

\subsubsection{Environmental Dimension}

- Coal mining can result in a number of adverse effects on the environment. Surface mining of coal completely eliminates existing vegetation, destroys the genetic soil profile, displaces and destroys wildlife and habitat, degrades air quality, alters current land uses and to some extent permanently changes the 
general topography of the area mined. This often results in a scarred landscape with no scenic value. Rehabilitation and reclamation mitigates some of these concerns.

- Mine tailings dumps produce acid mine drainage which can seep into waterways and aquifers, with consequences on ecological and human health. In case of collapse of underground mine tunnels, subsidence occurs over land surfaces. During actual mining operations methane, a known greenhouse gas may be released into the air. Due to movement, storage and redistribution of soil, the community of micro organisms and nutrient cycling process can be disrupted.

- Two significant negative impacts of mining are underground mine fire and ground subsidence. Both of these phenomena ultimately lead to ground instability. Such instability will not only hamper the future prospects of mining but will also affect stability of the ground structures. Significance of such instability problem lies in the fact that they endanger human security in densely populated areas like Jharia coal belt.

\subsection{Utilization Of Land In Jharia}

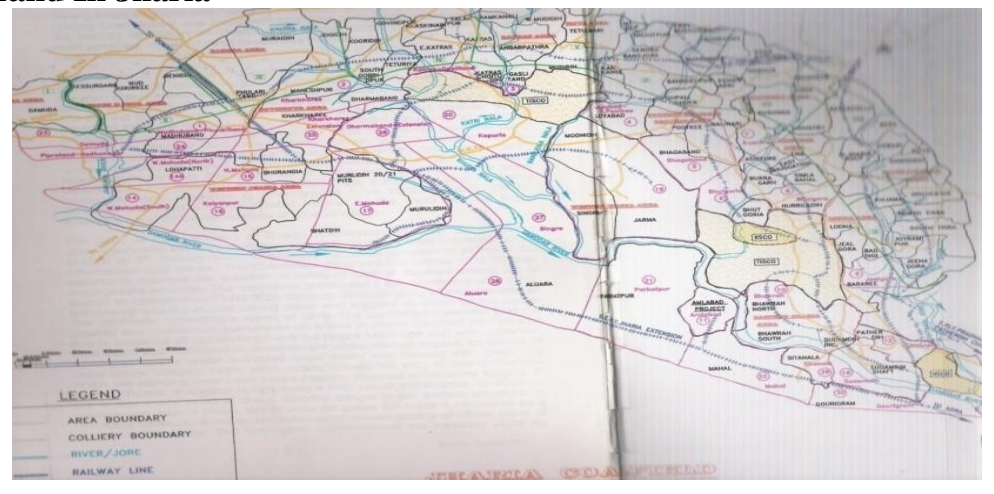

Though coal mining started in India about two centuries ago, commercial mining began in JCF in 1894 (Saxena, 1991). Mining picked up here at a fast pace due to availability of high quality coal at shallow depths and in thick seams. It played a significant role during the two World Wars by supplying an essential input to power and steel plants, and it continues to do so even today despite the sharp decline in its productivity and drastic deterioration of its environment in recent times, especially since late 1980's. Mining companies having surface rights over their leasehold areas built office buildings, workshops, dispensaries and even residential quarters in the mine premises above coal bearing areas.As JCF came into prominence as a hub of coal mining activities, the township of Jharia started coming up around 1898 (CMRI, 1997). Concentrated growth of dwellings in this town and its suburbs were the natural outcome of industrial growth. People from all economic cross-sections are residing in JCF; and obviously, their dwelling units range from hutments to concrete units with modern facilities of sanitation.

Based on the types of land ownership, these dwellings may be broadly classified as:

$>$ company quarters, colonies and office complexes;

$>$ private buildings on legally acquired land;

$>$ private structures on illegitimately occupied lands on the mining/mined out areas where the surface rights are with the mining companies; and

$>$ illegal private constructions on the protected lands along roads, railway lines or streams.

Mining directly employs about 100,000 people, who comprise around $10 \%$ of the total population of the coalfield (Saxena N.C), more than $85 \%$ of the working population of the whole of Dhanbad district depends on mining and related activities (Pan B.N). JCF is one of the most densely populated areas in the world with more or less 2000 people living in each square kilometre.

JCF has a mixed population composed mainly of settlers who has migrated here from almost all states of India for their profession leading to a steady upsurge in the concentration of settlements. Whilst in 1925, dwelling land was only $9 \%$ of this mining belt, it was in excess of 30\% in late 1980s or early 1990s (Saxena N.C., CMRI). Simultaneously, the share of agricultural land has come down from $70 \%$ in the early years to merely $40 \%$ in recent years (Saxena N.C).

The JCF region is divided into 12 mining areas:

- Kustore

- Lodna

- Pootki

- Kusunda

- Sijua

- Eastern Jharia 
- Govindpur

- Bastacolla

- Katras

- Mahuda

- Chanch Victoria

- Katras Project Area

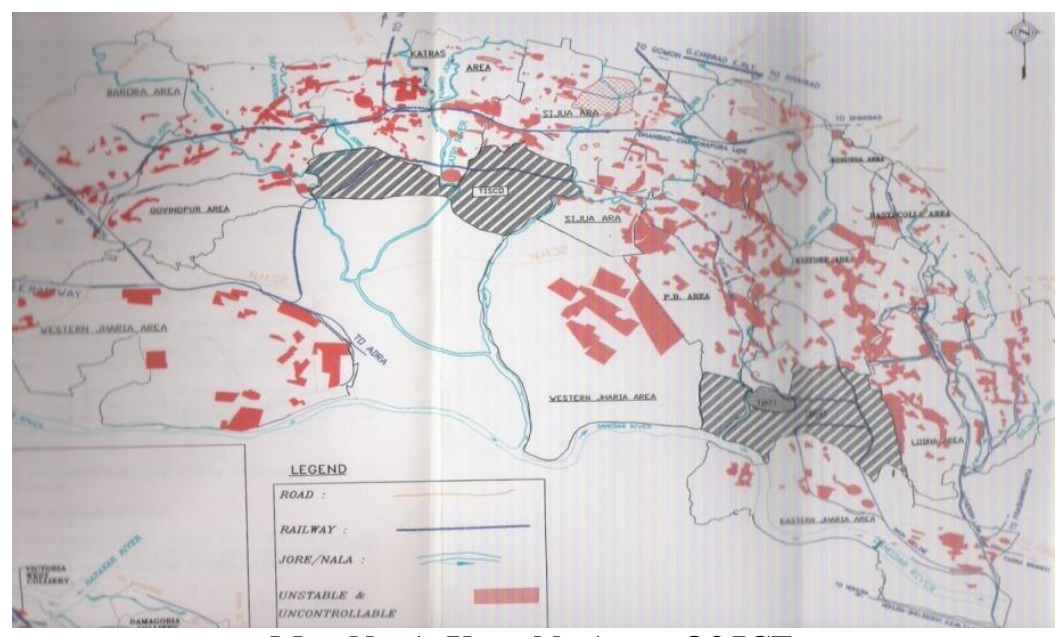

Map No. 1: Unstable Areas Of JCF

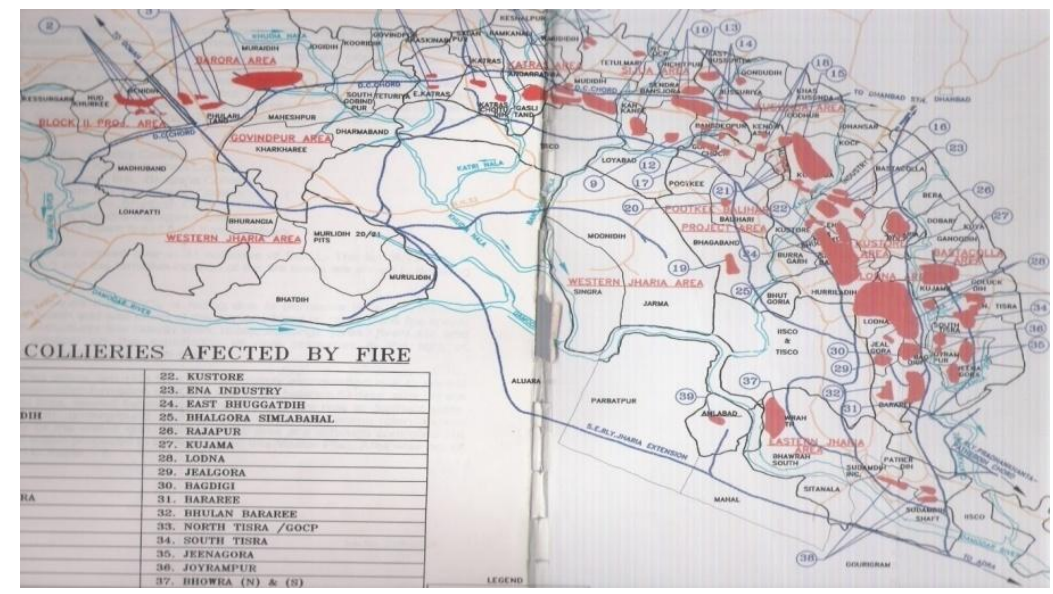

Map No. 2: Fire Afftected Areas Of JCF

\subsection{Selection Of Study Sites}

The stability of dwellings in JCF, ranging from huts to pucca houses, had been categorised in four groups, based on status of different seams, position of fire and visible signs of instability. Category I denotes stable ground, Category II is partly unstable ground, that in Category III is unstable and Category IV denotes critically unstable ground. According to this study, the dwellings in the critically unstable areas of Category IV need immediate evacuation.

Number of settlements under different categories are as follows:

\begin{tabular}{|l|l|l|l|l|}
\hline Category & $\begin{array}{l}\text { No. } \\
\text { Settlements }\end{array}$ & No. Of Dwellings & Area (sq.km) & Estimated Population \\
\hline I & $217(52.8 \%)$ & $50,185(52.8 \%)$ & $14,409.16(43.21 \%)$ & $200,740(52.8 \%)$ \\
\hline II & $57(13.9 \%)$ & $21,098(22.2 \%)$ & $11,547.86(34.63 \%)$ & $84,392(22.2 \%)$ \\
\hline III & $52(12.6 \%)$ & $10,057(10.6 \%)$ & $1,880.22(5.64 \%)$ & $40,228(10.6 \%)$ \\
\hline IV & $85(20.7 \%)$ & $13,720(14.4 \%)$ & $5,510.31(16.52 \%)$ & $54,880(14.4 \%)$ \\
\hline Total & $411(100 \%)$ & $95,060(100 \%)$ & $33,347.55(100 \%)$ & $380,240(100 \%)$ \\
\hline
\end{tabular}


The number of unstable villages and number of fires in each of the 12 mining areas are tabulated as below:

\begin{tabular}{|l|c|c|c|c|c|c|c|c|c|c|c|}
\hline \multirow{2}{*}{ Area } & \multirow{2}{*}{$\begin{array}{l}\text { No. Of } \\
\text { fires }\end{array}$} & \multicolumn{4}{|c|}{ No. Of Unstable Colliery } & \multicolumn{3}{l|}{ No. Of Unstable Villages } \\
\cline { 2 - 15 } & I & II & III & IV & Total & I & II & III & IV & Total \\
\hline Kustore & 9 & 7 & 5 & 4 & 6 & 22 & 19 & 13 & 10 & 19 & 61 \\
\hline Lodna & 13 & 3 & 4 & 5 & 6 & 18 & 12 & 5 & 22 & 14 & 53 \\
\hline Bastacolla & 2 & 6 & 2 & 3 & 3 & 14 & 13 & 5 & 4 & 4 & 26 \\
\hline Eastern Jharia & 4 & 5 & 2 & 1 & 1 & 9 & 37 & 3 & 1 & 1 & 42 \\
\hline Chanch Vistoria & - & 5 & 3 & - & - & 8 & 14 & 3 & - & - & 17 \\
\hline Pootki & 4 & 7 & 2 & 1 & 2 & 12 & 42 & 8 & 2 & 7 & 59 \\
\hline Kusunda & 7 & 7 & 2 & 3 & 5 & 17 & 28 & 2 & 4 & 6 & 40 \\
\hline Sijua & 9 & 1 & 1 & 3 & 6 & 11 & 2 & 1 & 8 & 26 & 37 \\
\hline Katras & 4 & 4 & 2 & - & 3 & 9 & 4 & 5 & - & 6 & 15 \\
\hline Govindpur & - & 8 & 7 & - & - & 15 & 28 & 10 & - & - & 38 \\
\hline Mahuda & - & 3 & - & - & - & 3 & 18 & - & - & - & 18 \\
\hline
\end{tabular}

On the basis of the above information the study areas are ranked according to their level of vulnerabilty:

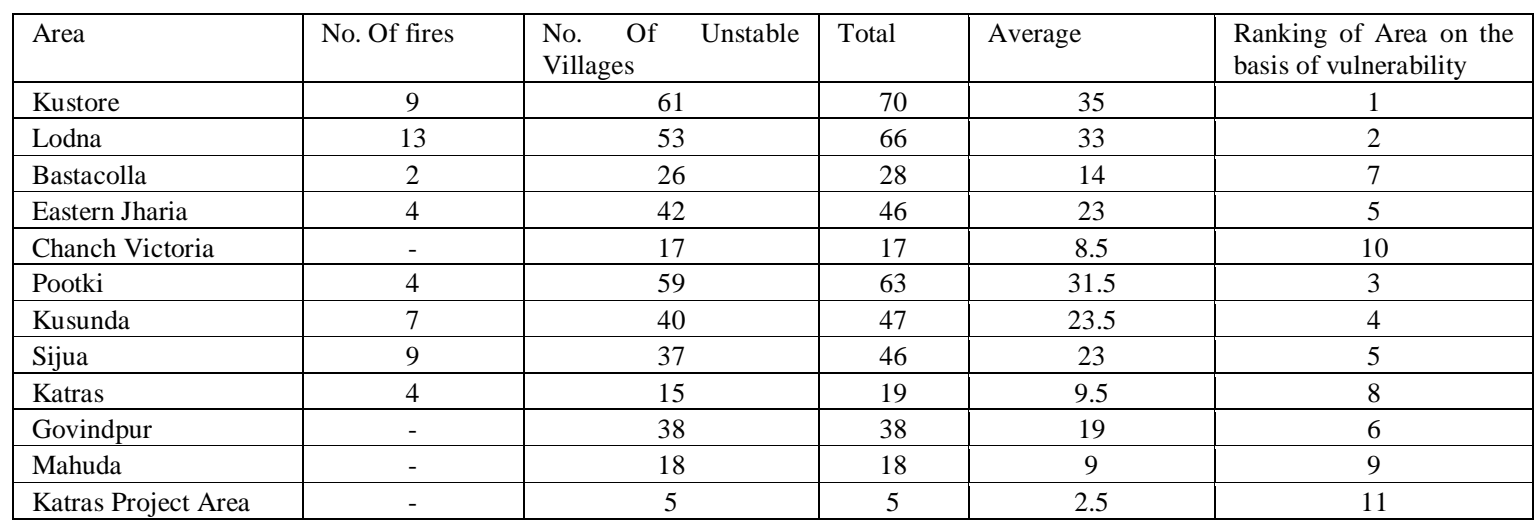

From the ranking obtained from the previous table, some unstable areas have been selected. The justification of selection of the unstable areas are: The target population and target areas for Resettlement \& Rehabilitation are with respect to the unstable mining areas only. In other words, the question of $R \& R$ are not applicable in case of the stable mining areas. Unstable mining areas have been ranked on the basis of the status and level of the QOL of the inhabitants and the status and quality of the habitat of the respective collieries.

Therefore, the selected unstable areas are as follows:

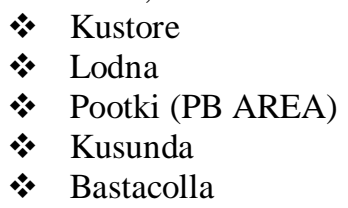

\subsection{Methodology For Qol Index Evaluation}

1. Reconnaissance socio-economic survey to be conducted at and around the study area for preliminary conception on habits and habitats, major means of livelihood, basic needs, social status, economic stratification of people there.

2. Subsequently, the factors affecting the Quality of Life (QOL) of the people in the study area to be identified.

3. Based on the identified parameters, a questionnaire to be formed to determine the QOL of the people in the areas, taking into account the level of satisfaction of each respondent for each parameter. 
a. The Level of Satisfaction for each parameter to be graded from 0.1 to 0.9 as listed below.

\begin{tabular}{|l|l|l|l|l|l|}
\hline $\begin{array}{l}\text { LEVEL } \\
\text { SATISFACTION }\end{array}$ & $\begin{array}{l}\text { Highly Satisfied } \\
(\mathrm{HS})\end{array}$ & Satisfactory (SA) & $\begin{array}{l}\text { Neutral } \\
(\mathrm{NE})\end{array}$ & Not Satisfied (NS) & $\begin{array}{l}\text { Highly } \\
(\mathrm{HU})\end{array}$ \\
\hline VALUES ON SCALE & 0.9 & 0.7 & 0.5 & 0.3 & 0.1 \\
\hline
\end{tabular}

Virtually the scale ranges from 0 to 1 . However, the extreme value of 0 for very low level of satisfaction i.e. Highly Unsatisfied (HU), and that of 1 for very high level of satisfaction i.e. Highly Satisfied (HS) are too utopian and are qualitatively difficult to assign. Hence, for Highly Unsatisfied (HU) and Highly Satisfied (HS), values allotted are 0.1 and 0.9 respectively.

b. The observations from the survey to be recorded as per the above scale as subjective views about satisfaction levels for the selected parameters. Satisfaction Level of the socio-economic parameters will then be represented graphically (Table 1.1).

4. Quantification of Subjective Views - Frequency of satisfaction level for each socio-economic parameter to be tabulated. Frequency of each parameter to be multiplied by the corresponding value of the level of satisfaction to which it belongs and summated to obtain the total weightage for each parameter. Average value of level of satisfaction for each parameter to be calculated and tabulated. Level of Satisfaction gives the Index of Satisfaction (Y) for each parameter (Table 1.3).

5. Objective view to be formulated based on the availability of the socio-economic parameters and their affordability on the part of the sample households.

6. Pair Comparison Test for Ranking of Factors: Significance of each parameter depending on its availability to be assigned with the help of Paired Comparison Test. The relative level of availability of each chosen pair of factors to be assessed using the following +4 to -4 scale.

\begin{tabular}{|l|l|}
\hline SCALE & INDEX \\
\hline+4 & $1^{\text {st }}$ abundantly available than $2^{\text {nd }}$ \\
\hline+3 & $1^{\text {st }}$ very much more available than $2^{\text {nd }}$ \\
\hline+2 & $1^{\text {st }}$ definitely more than $2^{\text {nd }}$ \\
\hline+1 & $1^{\text {st }}$ slightly more available than $2^{\text {nd }}$ \\
\hline 0 & $1^{\text {st }}$ has same availability as $2^{\text {nd }}$ \\
\hline-1 & $1^{\text {st }}$ slightly less available than $2^{\text {nd }}$ \\
\hline-2 & $1^{\text {st }}$ definitely less available than $2^{\text {nd }}$ \\
\hline-3 & $1^{\text {st }}$ very much less available than $2^{\text {nd }}$ \\
\hline-4 & $1^{\text {st }}$ scarcely available than $2^{\text {nd }}$ \\
\hline
\end{tabular}

The parameter to which a value will be assigned should be considered as the $1^{\text {st }}$ factor and the parameter with which the comparison will be done, should be taken as the $2^{\text {nd }}$ factor. The surveyors should assign these values depending on both their views and the above-obtained Index of Satisfaction. All the values assigned to a particular parameter after each comparison to be summated considering their positive and negative values. Next step is to calculate the average values for each parameter by dividing the total value assigned to a particular parameter by the number of times it will be compared. These values give the Index of Availability (X) of the parameters (Table 1.2).

Assigning the above values to each parameter leads to the ranking of the parameters based on their availability.

7. After ranking of the parameters (Table 1.4), they should be categorised based on their priority into three categories of Basic Amenities, i.e., I, II and III.

8. In the final table (Table 1.5), both the Index of Satisfaction $(\mathrm{Y})$ and Index of Availability $(\mathrm{X})$ are tabulated as per the ranking of factors. The next step is to summate the values $\mathrm{X}$ and $\mathrm{Y}$ for each parameter and then calculate their average. Their average value gives equal importance to both the subjective and objective views. The average values for all the parameters to be then summated and finally divided by the total number of parameters to find the QOL Index for the study area. 
Quality of Life Analysis: Socio-economic Perspective with reference to Jharia Coalfield

TABLE 1.1: Level Of Satisfaction Of The Selected Socio-Economic Parameters Among The Sample Units

\begin{tabular}{|c|c|c|c|c|c|c|c|c|c|c|}
\hline \multicolumn{11}{|c|}{ SATISFACTION LEVEL BASED ON SUBJECTIVE VIEWS } \\
\hline \multirow[b]{2}{*}{$\begin{array}{l}\text { SAMPLE } \\
\text { FRAME }\end{array}$} & \multicolumn{10}{|c|}{ SOCIO-ECONOMIC PARAMETERS } \\
\hline & $\begin{array}{l}\text { Health } \\
\text { Centre } \\
\mathrm{s}\end{array}$ & $\begin{array}{l}\text { Educatio } \\
\mathrm{n}\end{array}$ & \multicolumn{2}{|c|}{$\begin{array}{l}\text { Transport } \\
\& \text { Commu- } \\
\text { nication }\end{array}$} & $\begin{array}{l}\text { Drinking } \\
\text { Water } \\
\text { Availabil } \\
\text { ity }\end{array}$ & $\begin{array}{l}\text { Electrici } \\
\text { ty }\end{array}$ & $\begin{array}{l}\text { Physical } \\
\& \text { Social } \\
\text { Environme } \\
\text { nt } \\
\text { (religious } \\
\text { buildings) } \\
\end{array}$ & $\begin{array}{l}\text { Recreati } \\
\text { on } \\
\text { Facility } \\
\& \\
\text { notable } \\
\text { sites } \\
\end{array}$ & $\begin{array}{l}\text { Social } \\
\text { Security } \\
\text { (festivals } \\
\text { celebrate } \\
\text { d) }\end{array}$ & $\begin{array}{l}\text { Site } \\
\text { Conditi } \\
\text { on } \\
\text { (Subsid } \\
\text { ence/Fir } \\
\text { e) }\end{array}$ \\
\hline Ghanoodih (2) & $\mathrm{HU}$ & $\mathrm{HU}$ & NE & \multicolumn{2}{|l|}{$\mathrm{HU}$} & $\mathrm{NE}$ & $\mathrm{HU}$ & $\mathrm{HU}$ & $\mathrm{NE}$ & $\mathrm{NE}$ \\
\hline Alkusa (5) & HS & HS & NE & \multicolumn{2}{|l|}{ NE } & $\mathrm{NE}$ & HS & NE & NE & NS \\
\hline Kustore (11) & SA & SA & NS & \multicolumn{2}{|l|}{ NS } & NS & HS & NE & NS & SA \\
\hline Ena (4) & NE & HS & SA & \multicolumn{2}{|l|}{ SA } & SA & HS & $\mathrm{HU}$ & SA & $\mathrm{NE}$ \\
\hline Rajapur (4) & HS & HS & NE & \multicolumn{2}{|l|}{$\mathrm{NE}$} & $\mathrm{NE}$ & SA & $\mathrm{HU}$ & NE & NS \\
\hline E. Bhagatdih (7) & SA & HS & $\mathrm{HU}$ & \multicolumn{2}{|l|}{$\mathrm{HU}$} & $\mathrm{HU}$ & $\mathrm{HS}$ & $\mathrm{HU}$ & $\mathrm{HU}$ & $\mathrm{HU}$ \\
\hline Dhansar (3) & NS & NE & $\mathrm{NE}$ & \multicolumn{2}{|l|}{$\mathrm{NE}$} & NE & HS & NE & $\mathrm{NE}$ & $\mathrm{HU}$ \\
\hline Kusunda (1) & $\mathrm{HU}$ & $\mathrm{HU}$ & HS & \multicolumn{2}{|l|}{$\mathrm{HU}$} & HS & $\mathrm{HU}$ & $\mathrm{HU}$ & HS & $\mathrm{HU}$ \\
\hline Godhar (1) & $\mathrm{HU}$ & $\mathrm{HU}$ & HS & \multicolumn{2}{|l|}{ HS } & HS & $\mathrm{HU}$ & $\mathrm{HU}$ & HS & $\mathrm{HU}$ \\
\hline $\begin{array}{ll}\text { Khas } & \text { Kusunda } \\
(1) & \\
\end{array}$ & $\mathrm{HU}$ & $\mathrm{NE}$ & $\mathrm{NE}$ & \multicolumn{2}{|l|}{$\mathrm{NE}$} & $\mathrm{NE}$ & HS & $\mathrm{NE}$ & $\mathrm{HS}$ & $\mathrm{HU}$ \\
\hline Basseriya(1) & $\mathrm{NE}$ & HS & $\mathrm{NE}$ & \multicolumn{2}{|l|}{$\mathrm{NE}$} & $\mathrm{NE}$ & $\mathrm{HS}$ & $\mathrm{HS}$ & $\mathrm{NE}$ & $\mathrm{HU}$ \\
\hline $\begin{array}{ll}\text { East } & \text { Basseriya } \\
(1) & \\
\end{array}$ & $\mathrm{NE}$ & $\mathrm{HS}$ & $\mathrm{NE}$ & \multicolumn{2}{|l|}{ NE } & $\mathrm{NE}$ & HS & $\mathrm{NE}$ & $\mathrm{NE}$ & $\mathrm{HS}$ \\
\hline Kenduadih (20) & $\mathrm{HU}$ & SA & SA & \multicolumn{2}{|l|}{$\mathrm{NE}$} & SA & HS & HS & SA & $\mathrm{HU}$ \\
\hline Gopalichak (11) & $\mathrm{HU}$ & HS & $\mathrm{HS}$ & \multicolumn{2}{|l|}{$\mathrm{HS}$} & HS & HS & $\mathrm{HU}$ & HS & SA \\
\hline HydroMining (7) & $\mathrm{HU}$ & $\mathrm{NE}$ & NS & \multicolumn{2}{|l|}{ NS } & NS & HS & NE & NS & SA \\
\hline Balihari (8) & $\mathrm{HU}$ & HS & $\mathrm{HS}$ & \multicolumn{2}{|l|}{ HS } & $\mathrm{HS}$ & HS & NS & HS & $\mathrm{HS}$ \\
\hline Pootki (2) & $\mathrm{HU}$ & $\mathrm{HS}$ & HS & \multicolumn{2}{|l|}{ HS } & $\mathrm{HS}$ & HS & $\mathrm{HU}$ & HS & HS \\
\hline North Tisra (1) & $\mathrm{HU}$ & $\mathrm{HU}$ & $\mathrm{HS}$ & \multicolumn{2}{|l|}{ HS } & $\mathrm{HS}$ & $\mathrm{HS}$ & $\mathrm{HU}$ & $\mathrm{HS}$ & $\mathrm{HS}$ \\
\hline Jealgora (14) & NS & HS & $\mathrm{NE}$ & \multicolumn{2}{|l|}{$\mathrm{NE}$} & $\mathrm{NE}$ & HS & $\mathrm{NE}$ & $\mathrm{NE}$ & NS \\
\hline Bareree (11) & HS & HS & SA & \multicolumn{2}{|l|}{ SA } & SA & $\mathrm{HU}$ & NE & SA & $\mathrm{HU}$ \\
\hline
\end{tabular}

TABLE 1.2: Pair Wise Comparison Test On Availability Of Parameters And Their Ranking

\begin{tabular}{|c|c|c|c|c|c|c|c|c|c|c|c|c|c|}
\hline PARAMETERS & 1 & 2 & 3 & 4 & 5 & 6 & 7 & 8 & 9 & $\begin{array}{l}\text { SU } \\
\text { M }\end{array}$ & $\begin{array}{l}\text { AVERA } \\
\text { GE }(X)\end{array}$ & $\begin{array}{l}\text { SCALE } \\
\text { CONVE } \\
\text { RSION }\end{array}$ & $\begin{array}{l}\text { RANKIN } \\
\text { G }\end{array}$ \\
\hline Health Centres & - & -4 & -3 & -3 & -3 & -4 & 1 & -3 & -1 & -20 & -2.5 & 0.1875 & 2 \\
\hline Education & 4 & - & 1 & 1 & 1 & -1 & 4 & 1 & 3 & 14 & 1.75 & 0.71875 & 8 \\
\hline $\begin{array}{ll}\text { Transport } & \& \\
\text { Communication } & \end{array}$ & 3 & -1 & - & 1 & 0 & -2 & 3 & -1 & 3 & 6 & 0.75 & 0.59375 & 5 \\
\hline $\begin{array}{ll}\text { Drinking } & \text { Water } \\
\text { Availability } & \\
\end{array}$ & 3 & -1 & -1 & - & -1 & -2 & 3 & -1 & 2 & 2 & 0.25 & 0.53125 & 4 \\
\hline Electricity & 3 & -1 & 0 & 1 & - & -2 & 3 & -1 & 3 & 6 & 0.75 & 0.59375 & 5 \\
\hline $\begin{array}{lll}\begin{array}{l}\text { Physical \& } \\
\text { Environment }\end{array} & \text { Social } \\
\end{array}$ & 4 & 1 & 2 & 2 & 2 & - & 4 & 2 & 4 & 21 & 2.625 & 0.828125 & 9 \\
\hline $\begin{array}{lll}\begin{array}{l}\text { Recreation } \\
\text { notable sites }\end{array} & \text { Facility } & \& \\
\end{array}$ & -1 & -4 & -3 & -3 & -3 & -4 & - & -3 & -1 & -22 & -2.75 & 0.15625 & 1 \\
\hline Social Security & 3 & -1 & 1 & 1 & 1 & -2 & 3 & - & 3 & 9 & 1.125 & 0.640625 & 7 \\
\hline $\begin{array}{l}\text { Site Condition } \\
\text { (Subsidence/Fire) }\end{array}$ & 1 & -3 & -3 & -2 & -3 & -4 & 1 & -3 & - & -16 & -2 & 0.25 & 3 \\
\hline
\end{tabular}


Quality of Life Analysis: Socio-economic Perspective with reference to Jharia Coalfield

Table 1.3: Quantification of Satisfaction Level of the Basic Parameters based on the Views of the Respondents

\begin{tabular}{|c|c|c|c|c|c|c|c|c|c|c|c|c|}
\hline \multicolumn{13}{|c|}{ QUANTIFICATION OF SATISFACTION LEVEL BASED ON SUBJECTIVE VIEWS } \\
\hline FACTORS & \multicolumn{2}{|c|}{ HS (0.9) } & \multicolumn{2}{|c|}{ SA $(0.7)$} & \multicolumn{2}{|c|}{$\mathrm{NE}(0.5)$} & \multicolumn{2}{|c|}{ NS $(0.3)$} & \multicolumn{2}{|c|}{$\mathrm{HU}(0.1)$} & \multirow{2}{*}{$\begin{array}{l}\text { Summated } \\
\text { Value (Y) } \\
7.2\end{array}$} & \multirow{2}{*}{$\begin{array}{l}\begin{array}{l}\text { Average } \\
(\mathrm{Y})\end{array} \\
0.36\end{array}$} \\
\hline Health Centres & 3 & 2.7 & 2 & 1.4 & 3 & 1.5 & 2 & 0.6 & 10 & 1 & & \\
\hline Education & 11 & 9.9 & 2 & 1.4 & 3 & 1.5 & 0 & 0 & 4 & 0.4 & 13.2 & 0.66 \\
\hline Transport \& Communication & 6 & 5.4 & 3 & 2.1 & 8 & 4 & 2 & 0.6 & 1 & 0.1 & 12.2 & 0.61 \\
\hline Drinking Water Availability & 5 & 4.5 & 2 & 1.4 & 8 & 4.5 & 2 & 0.6 & 3 & 0.3 & 11.3 & 0.565 \\
\hline Electricity & 6 & 5.4 & 3 & 2.1 & 8 & 4 & 2 & 0.6 & 1 & 0.1 & 12.2 & 0.61 \\
\hline $\begin{array}{l}\text { Physical \& Social Environment } \\
\text { (religious buildings) }\end{array}$ & 15 & 13.5 & 1 & 0.7 & 0 & 0 & 0 & 0 & 4 & 0.4 & 14.6 & 0.73 \\
\hline $\begin{array}{l}\text { Recreation Facility \& notable } \\
\text { sites }\end{array}$ & 2 & 1.8 & 0 & 0 & 8 & 4 & 1 & 0.3 & 9 & 0.9 & 7 & 0.35 \\
\hline $\begin{array}{l}\text { SocialSecurity(festivals } \\
\text { celebrated) }\end{array}$ & 7 & 6.3 & 3 & 2.1 & 7 & 3.5 & 2 & 0.6 & 1 & 0.1 & 12.6 & 0.63 \\
\hline $\begin{array}{l}\text { Site Condition } \\
\text { Subsidence/Fire) }\end{array}$ & 4 & 3.6 & 3 & 2.1 & 2 & 1 & 2 & 0.6 & 8 & 0.8 & 8.1 & 0.405 \\
\hline & \multicolumn{12}{|c|}{ Total No. of Respondents - 20} \\
\hline & \multicolumn{12}{|c|}{ Y - Index of Satisfaction } \\
\hline
\end{tabular}

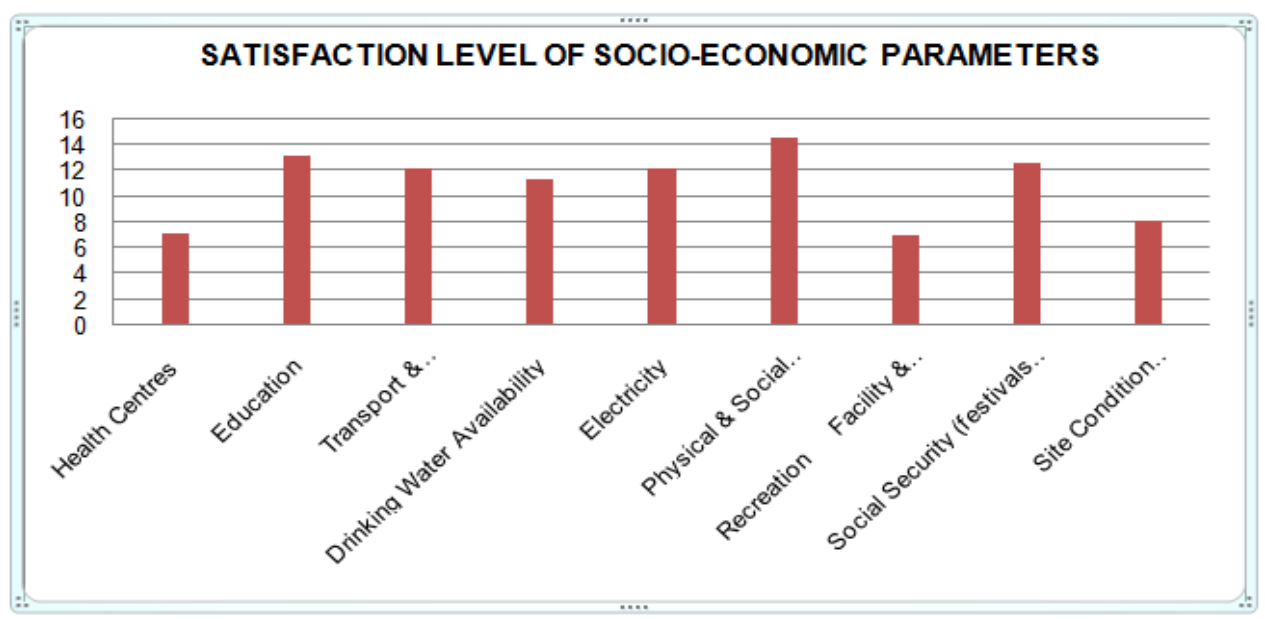

Table 1.4: Ranking of parameters

\begin{tabular}{|l|l|l|}
\hline FACTORS AFTER RANKING & X & Y \\
\hline Recreation Facility \& notable sites & 0.35 & 0.15625 \\
\hline Health Centres & 0.36 & 0.1875 \\
\hline Site Condition (Subsidence/Fire) & 0.41 & 0.25 \\
\hline Drinking Water Availability & 0.57 & 0.53125 \\
\hline Electricity & 0.61 & 0.59375 \\
\hline Transport \& Communication & 0.61 & 0.59375 \\
\hline Social Security \& festivals celebrated & 0.63 & 0.640625 \\
\hline Education & 0.66 & 0.71875 \\
\hline Social Environment & 0.73 & 0.828125 \\
\hline
\end{tabular}

\subsection{Interpretation Of Ranking}

After tabulating the satisfaction level and availability level of the parameters, we get the ranking of these parameters on $0.1-0.9$ scale. Ranking indicates that the parameters which are having lesser value have a higher significance in the region, as they are in a very poor condition. These parameters need urgent attention for their development if the Quality of Life of the inhabitants has to be improved. The parameters with higher value are lower in the order. Their condition is good in the region. These parameters do not need urgent attention. From the above ranking we can categorize them accordingly:

Category I: Recreation facility, health centers and site condition( subsidence/fire) are in a very bad condition and therefore require urgent attention.

Category II: Drinking water availability, electricity supply and transport \& communication network have a neutral condition therefore in category II of priority level. 
Category III: This include social security, education and social environment. These are in good condition in the study areas and therefore are having less priority.

Table 1.5: Determination of Quality of Life

\begin{tabular}{|l|c|c|c|c|}
\hline & \multicolumn{1}{|l|}{$\begin{array}{l}\text { OF } \\
\text { INDEX INDEX OF AVAILABILITY } \\
\text { RANKED FACTORS }\end{array}$} & $\begin{array}{l}\text { SUM } \\
\text { X+Y/2 }\end{array}$ \\
\hline $\begin{array}{l}\text { Recreation Facility \& notable } \\
\text { sites }\end{array}$ & 0.35 & 0.15625 & 0.50625 \\
\hline Health Centres & 0.36 & 0.1875 & 0.5475 & 0.27375 \\
\hline $\begin{array}{l}\text { Site Condition } \\
\text { Subsidence/Fire) }\end{array}$ & 0.41 & 0.25 & 0.66 \\
\hline Drinking Water Availability & 0.57 & 0.53125 & 1.10125 & 0.550625 \\
\hline Electricity \& & 0.61 & 0.59375 & 1.20375 & 0.601875 \\
\hline Transport \& Communication & 0.61 & 0.59375 & 1.20375 & 0.601875 \\
\hline Social Security & 0.63 & 0.640625 & 1.270625 & 0.635313 \\
\hline Education & 0.66 & 0.71875 & 1.37875 & 0.689375 \\
\hline Physical \& Social Environment & 0.73 & 0.828125 & 1.558125 & 0.779063 \\
\hline
\end{tabular}

\section{QOL INDEX:}

From the previous table, we get the summated value of $(\mathrm{X}+\mathrm{Y}) / 2$ as 4.715

Therefore, QOL Index $=4.715 / 9=0.52$

[9 being the number of parameters taken for the study]

\section{Interpretation:}

0.52 of QOL Index indicates that the study area is having neutral level of Quality of Life.

\section{Conclusion}

Application of the technique: QOL Index and the ranking of the socio-economic parameters in a particular study area give a picture of the socio-economic condition of that particular site. This helps to determine the basic priorities for each study area. The conditions which are lacking in the area become the significant factors in the priority list. Therefore, QOL study is beneficial for the policy makers. It will help to frame developmental policies for any area.

\section{References}

[1]. Arya, P. K. and Ghosh, A. K. (2004): Management of Mineral resource in Jharkhand: Importance of Rehabilitation of Closed Coal and Copper Mines, Proc. Nat. Sem. Role of Mining Industry in Economic and Industrial Development of Jharkhand - Problems and Prospects (JHMIN-04), ISM, February 28.

[2]. Bhattacharya, Debjit (2003), Article in SambadPratidin, September 11 \& 12, 2003.

[3]. Census of India, Provisional Population Total - India, 1991 \& 2001.

[4]. CMRI (1997), Report of the Study, Stability Status of Dwellings in Jharia Coalfield, Part I \& II.

[5]. CMRI \& NEERI (2001), Report of Dissemination Package on Carrying Capacity Based Development Planning of DamodarRiver Basin.

[6]. CMRI (2002), Proposal on Development of Comprehensive Technology for Disaster Prevention \& Management for Jharia Coalfield, Memorandum submitted for the consideration of Governing Body of CSIR/Expenditure Finance Committee (EFC).

[7]. Das, Biswanath; Bhattacharya, Goutam; Quality of Life, Edited Volume of National Seminar on Quality of Life, 16-18 November 2002.

[8]. Discussions in the LokSabha on Fires in Coalfield, August 19, 1992

[9]. Erady, R. V. and Prasad, P. R. (2004): Revival of BCCL - A Must for Overall Development of Jharkhand State; Proc. Nat. Sem. Role of Mining Industry in Economic and Industrial Development of Jharkhand - Problems and Prospects (JHMIN-04), ISM, February 28

[10]. Ghosh, C. N., Mondal,P.,Kumbhakar,P. K., Ghosh, D. and Sekhar, S. (2004): The Stability of Jharia Coalfield Using Ash Stowing An Approach, Proc. Nat. Sem. Role of Mining Industry in Economic and Industrial Development of Jharkhand - Problems and Prospects (JHMIN-04), ISM, February 28.

[11]. Jawed, M. (2000): Underground Mining of Thick Coal Seams in Bihar-Jharkhand - Some Related Problems and Issues of Concern, Geology and Mineral Resources of Bihar and Jharkhand, published by Institute of Geoexploration\& Environment and ISM, p. 257272.

[12]. Pan, B.N. (2003): Future Mining Strategy for Bharat Coking Coal Ltd., Proc. Nat. Workshop on Reinventing Jharia Coalfield, Organised by Dhanbad Chapter of Mining, Geological and Metallurgical Institute of India, August 22-23, ISM, Dhanbad.

[13]. Quality of Life; Wikipedia - The free Encyclopaedia.

[14]. Raju, E.V.R. and Ghosh, Rekha (2003): Post Mining Land Use Planning for Jharia Coalfield - A GIS Approach, Proc. Nat. Workshop on Reinventing Jharia Coalfield, Organised by Dhanbad Chapter of Mining, Geological and Metallurgical Institute of India, August 22-23, ISM, Dhanbad.

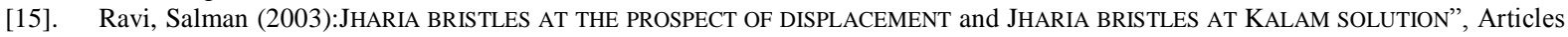
in The Telegraph, August 7. 
[16]. Samanta, B. K. and Samaddar, A. B. (2003): Environmental Management and Sustainable Development in Jharia Coalfield - Some Vital Issues, Proc. Nat. Workshop on Reinventing Jharia Coalfield, Organised by Dhanbad Chapter of Mining, Geological and Metallurgical Institute of India, August 22-23, ISM, Dhanbad.

[17]. SanyalBadal (2002):Ministry SETS TARGET DATE TO RELOCATE BCCL AREA PEOPLE; Article in The Hindu - Business Line, October 24.

[18]. Saxena, N.C. (1991): Subsidence Management in Jharia Coalfield, India - A Concept, Land Subsidence, Proc. Fourth Int. Symp. on Land Subsidence, May, IAHS Publ.No.200.

[19]. Saxena, N.C. (2003): Present Social Environment and Future Prospects for Jharia Coalfield, Proc. Nat. Workshop on Reinventing Jharia Coalfield, Organised by Dhanbad Chapter of Mining, Geological and Metallurgical Institute of India, August 22-23, ISM, Dhanbad.

[20]. Saxena, N. C. (2003): Jharia Coalfield Today, Tomorrow and Thereafter, http://www.geocities.com/vibhaskumar/jharia_ncs1.html.

[21]. Saxena, N. C. (2004): Strategies for Rehabilitation of Jharia Coalfield, Tech. Paper Meeting of MGMI, Dhanbad Chapter, January 24.

[22]. Sen, K., Das, N. S., Singh, A. K. and Dasgupta, R. (2003): Search for Appropriate Strategies on Coking Coal Utilization - A Pressing Need for Sustainable Development in Jharia Coalfield, Proc. Nat. Workshop on Reinventing Jharia Coalfield, Organised by Dhanbad Chapter of Mining, Geological and Metallurgical Institute of India, August 22-23, ISM, Dhanbad.

[23]. Singh, R. S. (2003: Jharia Coalfield: Revival and Long Term Sustainability, Proc. Nat. Workshop on Reinventing Jharia Coalfield, Organised by Dhanbad Chapter of Mining, Geological and Metallurgical Institute of India, August 22-23, ISM, Dhanbad.

[24]. Singh, T.N. (1997): Geo-environment of Indian Coalfields, $1^{\text {st }}$ Edition.

[25]. Thapar, M. K. (2003): Technical Solution vis-à-vis Human and Social problems prevailing in Jharia Coalfield, Proc. Nat. Workshop on Reinventing Jharia Coalfield, Organised by Dhanbad Chapter of Mining, Geological and Metallurgical Institute of India, August 22-23, ISM, Dhanbad.

[26]. Vijh, K.C. (2003): Reinventing Jharia Coalfield - Suggested Action Plan for Attitudinal Change to Achieve the Desired Results, Proc. Nat. Workshop on Reinventing Jharia Coalfield, Organised by Dhanbad Chapter of Mining, Geological and Metallurgical Institute of India, August 22-23, ISM, Dhanbad.

[27]. World Bank (1996): Mainstreaming Sustainability? The World Bank and the Rehabilitation of the Indian Coal Sector, Part 1, Berne Declaration position paper, May 13 